\title{
Peer Effects in Academic Cheating
}

\author{
Scott E. Carrell \\ Frederick V. Malmstrom \\ James E. West
}

\begin{abstract}
A B S T R A C T
Using self-reported academic cheating from the classes of 1959 through 2002 at the three major United States military service academies (Air Force, Army, and Navy), we measure how peer cheating influences individual cheating behavior. We find higher levels of peer cheating result in a substantially increased probability that an individual will cheat. One additional college student who cheated in high school drives approximately 0.33 to 0.47 additional college students to cheat. One additional college cheater drives approximately 0.61 to 0.75 additional college students to cheat. These results imply, in equilibrium, the social multiplier for academic cheating is approximately three.
\end{abstract}

\section{Introduction}

As far back as 1948, Solomon Asch reported that persons in social settings-for whatever reasons-will subscribe to the perceptions of the "erroneous majority" with a high degree of conformity, and these group perceptions will persist for many generations (Crutchfield 1955). More recently, the question of whether peers influence individual behavior has been widely studied in the economics literature. The role of peers is central to many education policy debates such as busing, affirmative action, and ability grouping. Peer effects also have been the focus in explaining the variation in crime rates across cities (Glaeser, Sacerdote, and Scheinkman

Scott E. Carrell is an assistant professor of economics at the University of California, Davis. Frederick $V$. Malmstrom is a visiting scholar in the Center for Character Development of the U.S. Air Force Academy in Colorado Springs. James E. West is a professor of economics at the U.S. Air Force Academy in Colorado Springs. The authors would like to thank all participants at the NBER Higher Education meetings, the Dartmouth College seminar and the Western Economic Association annual meetings for their numerous helpful comments. They are also grateful to the College Board for allowing us access to their historical archive of college admissions data. The data used in this article can be obtained beginning August 2008 through July 2011 from the authors: Scott E. Carrell, SeCarrell@ucdavis.edu FrederickV. Malmstrom, Fred.Malmstrom@usafa.edu; and JamesE.West, Jim.West@usafa.edu [Submitted December 2005; accepted January 2007]

ISSN 022-166X E-ISSN 1548-8004 (c) 2008 by the Board of Regents of the University of Wisconsin System

THE JOURNAL OF HUMAN RESOURCES • XLIII • I 
2003) or juvenile correctional facilities (Bayer, Pintoff, and Pozen 2005) and academic achievement across classrooms and schools (Graham 2006; Hanushek, et al. 2003; Hoxby and Weingarth 2006; Lefgren 2004). However, due to difficulties in measuring peer influence, there is a relatively small body of direct credible evidence of peer effects (see Sacerdote 2001; Zimmerman 2003; Stinebrickner and Stinebrickner 2006; Hoxby and Weingarth 2006). In fact, the most recently published research has drawn into question the very existence of peer effects in higher education (Foster 2006; Lyle 2007). Even less is known about the potential mechanisms that may drive peer influence.

Peer effects studies in higher education have primarily focused on measuring peer influence in academic achievement or social outcomes such as fraternity/sorority membership, while peer effects in "bad" collegiate behavior have been somewhat less studied. Kremer and Levy (2003) find that males who are assigned to roommates who reported drinking prior to college attendance had significantly lower grade point averages compared to those assigned to nondrinking roommates.

Although not explicitly mentioned, the academic cheating literature has hinted at possible peer influence in cheating. Stanard and Bowers (1970) found cheating higher among members of a fraternity or sorority, and Bowers (1964) found cheating higher among intercollegiate athletes. McCabe and Trevino (1993) found that the perception others were cheating was the major contributing factor to own academic cheating. On the surface, their results are quite compelling; however, the statistical methods used did not correct for endogeneity of the peer measure or self-selection of individuals into peer groups. That is, their statistical techniques used cannot reliably separate the effect of a peer group upon an individual from the effect of an individual upon the group. And in the presence of self-selection into groups, it is not possible to distinguish between peer influence and the effect of a jointly shared potentially unobservable attribute that causes members to join a group and behave in a like manner.

Abundant evidence indicates that cheating at American universities is widespread. A web-based survey conducted by the Center for Academic Integrity found that around 70 percent of recent graduates at participating colleges admitted to some form of academic cheating (McCabe 2005). Numerous web-based enterprises exist to facilitate academic cheating, from essay libraries, to sites that outsource computer science homework projects to India (Koyner 2006). At one level, academic cheating is an interesting cat and mouse game between the cheater and those who would prevent it. However, if a university degree is a valuable signal in the labor market allowing employers to separate high value employees from low value employees (Spence 1973), cheating diminishes the signal and thus erodes the value of a university degree. If, as a result of the diminished signal, employers pay a smaller wage premium for an employee with a university degree, rational workers would choose to invest less in this form of human capital (Becker 1962). Hence, we might expect higher levels of academic cheating, all else equal, to reduce human capital investment in education.

Using self-reported cheating from the classes of 1959 through 2002 at the three major U.S. military service academies (Air Force, Army, and Navy), we measure how peers influence individual cheating behavior. By correcting for endogeneity and potential selection bias, we find strong positive peer effects (or social interactions) in academic cheating. That is, all else equal, higher levels of peer cheaters result in 
an increased probability that an individual will cheat. The peer effect remains substantial and statistically significant when including academy (school) fixed effects, time fixed effects, and academy specific linear time trends, providing strong evidence of the existence of peer influence in academic cheating.

We identify through separate estimation procedures an exogenous (contextual or pretreatment) peer effect and an endogenous (during treatment) peer effect. ${ }^{1}$ The magnitudes of the peer effects are substantial. Results for the (first-order) exogenous peer effect indicate that one additional college student who cheated in high school "creates" approximately 0.33 to 0.47 additional college cheaters. Results for the (first-order) endogenous peer effect indicate that one additional college cheater "creates" approximately $0.61-0.75$ additional college cheaters. In equilibrium, these results imply the social multiplier for academic cheating is approximately three if a complete expansion of new cheaters begetting other new cheaters were to occur. As such, we consider this to be a long-run upper bound of the peer effects we measure.

We also find different magnitudes of peer effects from occasional versus frequent cheaters. In various specifications of our empirical models, the academies with the lowest levels of cheating have the highest levels of peers reporting of violations. This result leads us to believe the peer effect may be that of an evolving social norm.

\section{Measuring Peer Influence}

\section{A. Types of Peer Influence}

A proper model of how peers influence individual behavior must begin with a careful identification of the avenues of causation of such influence. Manski (1993) defines three distinct types of peer influence: (1) exogenous effects, (2) endogenous effects, and (3) correlated effects. Exogenous or contextual effects are the effects of pretreatment characteristics on own within-treatment performance. In the context of our study, the effect of college peer's behavior while in high school on college cheating would be an example of an exogenous effect. Endogenous effects, as the name would suggest, are the effects of contemporaneous peer behavior on own behavior. The effect of peer college cheating on own college cheating would be an example of an endogenous effect. Finally, correlated effects are the result of self-selection into a group on the basis of a shared characteristic. Individuals with similar backgrounds self-selecting into a fraternity known for its large collection of old exams would be an example of a correlated effect.

The economics literature hypothesizes several mechanisms through which peer effects may work. First, peer effects may be driven through evolving social norms or social stigma (Rasmussen 1995; Glaeser, Sacerdote, and Scheinkman 1996; Silverman 2004). Second, peer effects may be driven through learning, information

1. In identifying separate exogenous and endogenous peer effects, our models assume the peer effect is completely driven either through pre-academy characteristics or completely through peer behavior while at the academy. In actuality, the underlying peer effect is likely some combination of the two, which we can't identify in a single model. 
gathering, or network formation (Sutherland 1939; Foster and Rosenzweig 1995; Besley and Case 1994). Finally, Sah (1991) presents a model for crime that predicts the probability of being arrested diminishes as more individuals choose to engage in criminal activity. That is, there is congestion in law enforcement, where only a fixed number of criminals can be arrested. Most papers in the peer effects literature have focused on measuring the existence and magnitude of peer effects, and have presented little empirical evidence on the mechanism that may be causing the peer effect. One recent exception is Bayer, Pintoff, and Pozen (2005) who find evidence that peer effects in criminal activity are linked to networks formed in juvenile correction facilities.

\section{B. Empirical Identification of Peer Effects}

Although social psychologists have long believed in the concept of peer influence, actual measurement of such effects is quite arduous. Two main challenges exist in measuring peer influence. First, it is difficult to separate the group's influence on an individual's outcome from the individual's influence on the group (Vigdor and Nechyba 2004). This problem is often referred to as the endogeneity problem (Sacerdote 2001) or the reflection problem (Manski 1993). The second issue in measuring peer influence occurs because individuals tend to self-select into peer groups. In this case, it is difficult to separate statistically the effect peers are having on one another from shared attributes, possibly unobserved, that both cause self-selection into a group and cause observed behavior (Sacerdote 2001).

Resolving the first issue is typically handled by finding a suitable instrument for peer behavior that is exogenous with respect to the stochastic error component of the dependent variable. The dependent variable in our paper is the choice of whether or not to cheat while in college. For example, Figlio (2005) uses a strategy of instrumenting for classroom misbehavior using boy's names. ${ }^{2}$ Other studies have used the average characteristics of neighborhood parents as an instrument for peer behavior (for example Case and Katz 1991; Gaviria and Raphael 2001). Finally, a more recent strategy in the education peer effects literature has used lagged peer achievement as a (exogenous) proxy for current achievement (Betts and Zau 2004; Burke and Sass 2004; Hanushek et al. 2003; Vigdor and Nechyba 2004).

The selection problem has typically been resolved using situations in which a "natural experiment" occurs and individuals are randomly assigned to peer groups (Boozer and Cacciola 2001; Sacerdote 2001; Zimmerman 2003; Foster 2006; Lyle 2007). Another strategy, widely used in the primary education peer effects literature, is to exploit entry and exit into peer groups over time (Vigdor and Nechyba 2004; Betts and Zau 2004; Burke and Sass 2004; Hanushek et al. 2003; Hoxby and Weingarth 2006). This has typically been accomplished using large administrative panel data sets while employing a series of fixed effects models.

2. Figlio (2005) finds that boys with names more commonly given to girls are more prone to disciplinary problems in the classroom than boys who have more traditionally male names. His strategy uses a numeric index of the femininity of boy's names as an instrument for disciplinary infractions in the classroom. 


\section{The Service Academies}

The three major service academies (Air Force, Army, and Navy) are fully accredited undergraduate institutions of higher education, with each having an enrollment of approximately 4,200 students. Average SAT scores for the class of 2005 for each school ranged from 1,278 to 1,310 (Princeton Review 2006). Applicants are selected for admission on the basis of academic, athletic, and leadership potential. Acceptance rates for the schools are 13 to 18 percent, which is comparable to some of the most elite schools in the country (U.S. News 2007). ${ }^{3}$ All students attending a service academy receive a 100 percent scholarship to cover their tuition, room, and board. Each student receives a monthly stipend of $\$ 845$ to cover books, uniforms, a computer, and other living expenses. All students are required to graduate within four years ${ }^{4}$ and serve a five-year commitment as a commissioned officer in the United States Armed Services following graduation.

All three service academies have similar honor policies that strictly prohibit lying, cheating, or stealing. The honor codes in general, and academic cheating in particular, are taken very seriously. Lessons on honor, honorable behavior, and the honor code are a regular part of the military studies curriculum. In addition, each academy has an elaborate "honor system" run primarily by cadets/midshipman. Cadets/midshipmen who volunteer to administer the honor system thoroughly investigate each accusation of an honor violation. If evidence is found, an "honor board" of cadets/ midshipmen is convened to determine if the code was violated. If a cadet/midshipman is found to have committed an honor violation, sanctions up to and including removal from the academy are possible.

\section{Data}

\section{A. The Dataset}

Data for our study were gathered by Frederick Malmstrom, from 1986 to 2005 with more than 4,900 anonymous mail surveys to a random sample of United States Military Academy, United States Naval Academy, and United States Air Force Academy alumni listed in the Register of Graduates. ${ }^{5}$ The response rate was 42 percent, with

3. Due to their unique nature, it is difficult to compare the military academies to other colleges and universities. However, according to the Princeton Review (2006), students who considered attending the military academies also "looked at" institutions such as: Boston College, Brown, Bucknell, Clemson, Cornell, Duke, Georgetown, Harvard, Johns Hopkins, MIT, NYU, Princeton, Notre Dame, Virginia, and Yale. 4. Special exceptions are given for religious missions, medical "setbacks," and other instances beyond the control of the individual.

5. Malmstrom's survey originated as a behavioral psychology research project with a faculty member at the University of Dayton examining the effectiveness of honor codes. The first paper presented from the data was Malmstrom and Coffman (1991). As Malmstrom's survey was sent exclusively to service academy graduates, the data should be viewed as descriptive only of academy graduates, and not the academy population as a whole, since those who did not graduate for various reasons are not represented in the survey respondents. From 1998 to 2004, graduation rates at the three service academies ranged from 81 to 86 percent (Education Trust, 2007). We do not have any feasible way of conducting a random sample of nongraduates after they have departed their respective service academy. 
2,060 individuals responding with completed surveys. ${ }^{6}$ Participants were asked to identify from which service academy they graduated, and to which cohort (four-year) of graduating classes they belonged. Four-year cohorts were used instead of the actual graduating class-year with the hope of eliciting more honest survey responses from alumni not wanting to diminish the reputation of their graduating class, yet preserving the ability to identify peer-group influences in the data through time. The use of four-year cohorts as the applicable peer group is, in essence, measuring the peer "culture" of cheating within the respective academy at a given interval of time.

Respondents were asked the frequency of their own violations of academic and nonacademic aspects of the honor code as cadets/midshipmen, and their own attitudes and actions during their high school and academy years, attitudes that might help explain their individual behaviors. See Appendix 2 for a copy of the survey and Table 1 for a list of summary statistics of variables used in the study.

\section{B. Do Academy Graduates Truthfully Report Cheating Behavior?}

Due to the self-reported nature of the data and the sample selection, which only includes graduates from each academy, several potential concerns with our data sample exist. Studies have shown that individuals may overreport socially approved behaviors such as religious attendance, voting, and charity contributions (Presser and Stinson 1998; Hadaway et al. 1993; Parry and Crossley 1950; Presser and Traugott 1992) and underreport socially undesirable behaviors such as drug use and highrisk sexual activity (Gibson, Hudes, and Donovan 1999). Other socially undesirable behaviors such as smoking have been shown to be relatively accurate in self-reports (Patrick et al. 1994). Presser and Stinson (1998, p. 144-45) find that, "misreporting error is caused mainly by social desirability pressures associated with intervieweradministration." As such, our use of anonymous mail surveys should reduce potential error associated with misreporting.

The actual rate of cheating can never be known with certainty. However, if we assume that a stable proportion of actual cheaters are discovered and referred to the honor system, variations in the number of honor cases should be correlated with variations in self-reported incidents of academic cheating. Given the volatility of the number of honor cases and self-admitted cases of cheating, we can test whether the two series are cointegrated.

Data for the actual number of honor cases for one academy were provided to us by academic year from 1955 through 1994. We aggregated the yearly data and computed the average number of actual honor cases that occurred during the four-year period of enrollment for each graduating class cohort. ${ }^{7}$ We then computed the predicted number of individuals who committed an honor violation for each cohort using our survey data. ${ }^{8}$ In every cohort but one, the predicted number of violators exceeded the actual number of cases. We then regressed the actual number of cases

6. The response rate of 42 percent is similar to those found in mail surveys to nonprofit organizations (Hager et al. 2003)

7. The results for this analysis were consistent when using the number of honor boards convened and the number of convicted violations.

8. This figure was computed by multiplying the proportion of individuals who reported cheating by the graduating class size. 


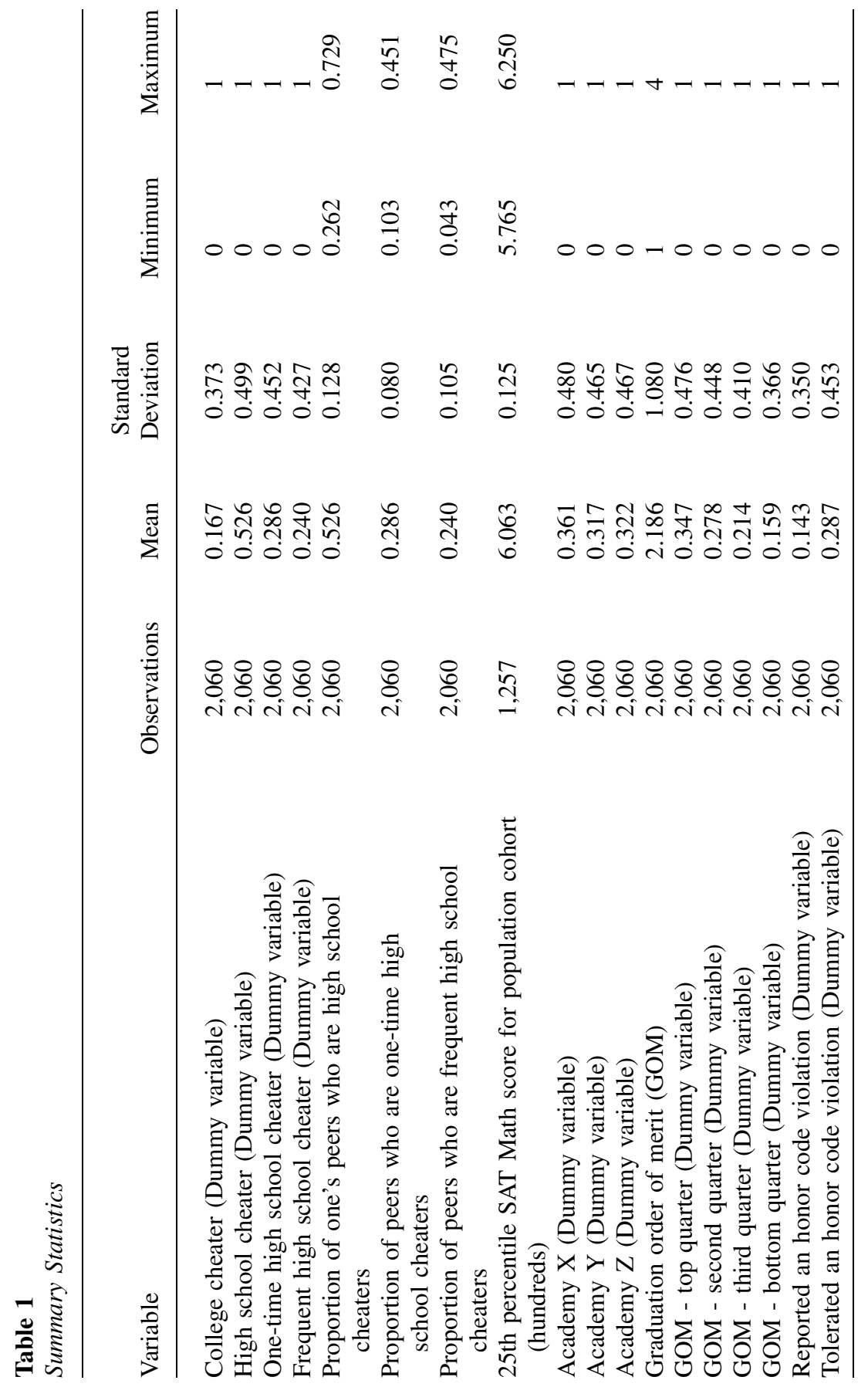


on the predicted number of violators, which resulted in positive and statistically significant coefficient of $0.37 .^{9}$ This result indicates that roughly one honor board occurred for every three admitted cheaters. We performed a Dickey-Fuller unit root test $^{10}$ on both predicted cheaters and actual cases, and in each case failed to reject the null hypothesis of a unit root at a five percent level of significance. We performed an additional Dickey-Fuller test on the regression residuals of cheating cases on selfadmitted cheating and found the two series to be cointegrated at a five percent level of significance. Although this result does not directly measure truthful reporting in the survey, we find it to be further evidence that our survey data is representative of the actual cheating behavior that occurred. ${ }^{11}$

We also tested the data for nonresponse bias. The overall survey response rate was 42 percent and the possibility exists that response rates could vary by respondent characteristics. While it is not possible to check the representativeness of our sample with regard to all characteristics, we can check with regard to graduation order of merit (GOM) by academy by cohort. Respondents were asked in which quartile of their class they graduated. Examining the summary statistics in Table 1, it is apparent that the top quartile of the GOM is overrepresented, and that self-reported cheating is positively correlated with the GOM. ${ }^{12}$ To test the robustness of our results with respect to this overrepresentation, we weighted each observation by the inverse probability of response for each GOM by academy by graduating class cohort and reestimated our models. Results for these specifications are shown in Appendix 1, Table A3. The magnitudes of estimated coefficients of interest are comparable if not slightly larger, indicating that the overrepresentation of individuals from the top quartile of the GOM, if anything, introduces a small negative bias on our peer effects estimates.

Finally, in asking service academy alumni the frequency with which they cheated and their attitudes toward the honor code they held while enrolled at a service academy, there exists the possibility of a "Lake Wobegon Effect," in which memories grow fonder over time. ${ }^{13}$ That is, it is possible that the upward trend in self-reported academic cheating over time is at least partially the result of changing memories over time. Given Malmstrom's survey data was collected in multiple samplings over an

9. The $t$-statistic on the predicted number of cheaters is 4.00 and the model $r$-squared is 0.65 .

10. We used a Dickey-Fuller test that a variable follows a unit-root process. The null hypothesis is that the variable contains a unit root (Dickey and Fuller 1979).

11. An additional concern arises due to nongraduates being omitted from the sample. If the expulsion of known cheaters were substantial, then the proportion of cheaters in the population of graduates would not be representative of the proportion of cheaters in the population of students. We were able to obtain honorcode-related expulsion data from one academy from 1955 through 1994. During this period, 1.4 percent of all individuals who attended the academy were expelled or resigned due to honor-code-related infractions. Due to the relatively small number of individuals who were expelled or resigned due to honor-code-related infractions, we feel that this potential bias is likely small.

12. The overall self-reported cheating rate is 16.7 percent, with 13.3 percent of individuals in the top quartile and 23.4 percent of individuals in the bottom quartile reported cheating. We recognize that the selfreported nature of our GOM variable is itself subject to potential biases in truthful responses.

13. The Lake Wobegon Effect is named for the fictional town featured in the radio series, A Prairie Home Companion. In Lake Wobegon, all of the children are above average. As an example of the Lake Wobegon Effect, Svenson (1981) found that 80 percent of survey respondents believed themselves to be in the top 30 percent of drivers by ability. 
18-year period, ${ }^{14}$ we can test whether in repeated random samplings of the same academy cohort, responses have significantly changed over time. To test for this, we compute average survey response of frequency of cheating for a given academy and graduating cohort from the original sampling, and again for the second sampling conducted in 2004. For the 30 groups (three academies, more than 10 graduating cohorts), we calculated a difference in means $t$-test (original sampling vs. 2004 sampling) and failed to reject the null hypothesis of no change in survey response for 28 groups at a 5 percent level of significance. ${ }^{15}$ As such, we do not find any significant evidence that the proportion of self-reported academic cheaters within a given academy and graduation cohort has changed over time. ${ }^{16}$

\section{Self-Selection into Academies}

Of importance to our study is that individuals within a given class cohort did not self-select into their chosen academy based on pretreatment high school cheating characteristics. ${ }^{17}$ The congressional nomination process for admittance to the three service academies provides some safeguard against systematic selection bias in our sample. For admittance to a service academy, an individual not only must meet the admissions requirements of the academy, but also must receive a nomination from his or her congressional representative or senator. ${ }^{18}$ Senators and representatives are allotted five total appointees at each service academy, with vacancies available only through graduation or withdrawal/expulsion. Therefore, the probability of admittance to any service academy in a given year is directly proportional to the number of available slots in one's congressional district/state. In an informal survey of congressional staff offices, we found the typical congressional office handles the nomination process for all three academies in one application, with applicants rankordering their preferences.

The application process may reduce selection bias in our sample in two ways. First, it ensures geographical diversity, with each service academy admitting students from every state and every congressional district in the United States. This prevents service academies from admitting a large proportion of students from any single area of the country, should the propensity to cheat have a geographic correlation. Second, the probability of admittance, regardless of qualifications, is a function of a random

14. Malmstrom's original survey was conducted in 1986. He surveyed subsequent graduating cohorts approximately every four years. In addition to gathering data on the final graduating cohort in 2004 , he surveyed again all previous graduating cohorts.

15. If two samples were randomly drawn from an identical distribution, one should expect a difference in means test to fail to reject the null hypothesis at a 5 percent level of significance in 95 percent of repetitions. 16. It is also possible that trends over time in our data could be due to evolving standards of what constitutes academic cheating. We do not believe this to be likely, given the amount of time devoted to honor education at the service academies, and the level of specificity with which honor education is conducted. At the Air Force Academy, military training includes regular lessons on the honor code, its meaning, and its centrality to military life. Incoming cadets are required to raise their right hands and swear to abide by the honor code. Similar programs also exist at the Military and Naval Academies.

17. Alternatively, because our data are self-reported cheating measures, we want to ensure there is no evidence of peer effects in the self-reporting of cheating.

18. In addition, there are a limited number of Presidential and Vice-Presidential nominations. 
element - the number of available slots in one's district. Hence, for students who apply to more than one academy, they may be randomly placed into one of the three academies depending on the number of available slots in their given district in a given year.

An indication of systematic selection bias would be one academy consistently admitting more or fewer high school cheaters over time relative to the other academies. To assess the likelihood of this, we plot in Figure 1 the proportion of self-reported high school cheaters by cohort over time for each academy. ${ }^{19}$ Note that each academy has at one point in the sample admitted the largest number of high school cheaters and at another point admitted the lowest number of high school cheaters. However, there appear to be some systematic differences across the service academies in the first several cohorts. To test whether this is a statistically significant effect, we regress self-reported individual high school (pretreatment) cheating on the high school cheating of college peers. ${ }^{20}$ Regression results are shown in Table 2. Zero correlation between these two variables would be expected in the case of pure random assignment. For the entire sample (Cohorts 1-11, shown in Column 1), the positive and statistically significant coefficient (0.500) in Specification 1 indicates potential positive selection bias when using the entire sample. However, when splitting the sample into Cohorts 1-4 (Column 2) and 5-11 (Column 3), the potential bias appears to be concentrated in the earlier cohorts of the data. For Specification 1, when the sample is limited to Cohorts 5-11, the coefficient on the peer high school cheating variable is positive, but no longer statistically significant. As a robustness check, in Specifications 2 and 3 we add academy specific linear time trends and academy fixed effects respectively. The statistically insignificant coefficients for all cohorts (1-11) and for Cohorts 5-11 provide further evidence that these controls help correct for potential selection bias in our estimates. ${ }^{21}$

Based on these findings, we also estimated our empirical models using only Cohorts $5-11$ to test the robustness of results while excluding the earlier cohorts. ${ }^{22}$ We also include academy and class fixed effects and academy specific linear time trends in the models, which are analogous to the "block" sorting controls as used by Sacerdote (2001) and Lyle (2007).

\section{Methods}

We estimate the peer effects in academic cheating using two separate approaches. In the first approach, we identify an exogenous peer effect by regressing individual outcomes on pretreatment variables to avoid simultaneous equation bias or the reflection problem. We specify the frequency of college academic cheating as a

19. High school cheaters are defined someone giving a \#2 through \#7 response to Question 16 of the survey, indicating at least one to three total cheating incidents while in high school.

20. We include a year fixed effect in these models to account for differences in high school cheating over time.

21. Nearly identical results are found when the selection estimates are weighted by the inverse probability of response for each GOM, academy, and graduating class cohort to adjust for potential nonresponse bias. 22. Results when using the subsample are shown in Appendix 1, Tables A1 and A2 and are largely consistent with those estimated using the full sample. 


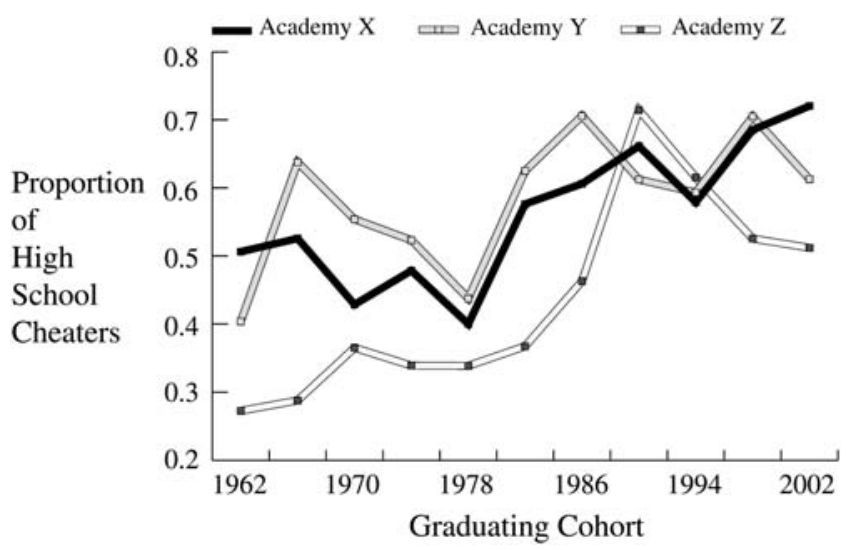

\section{Figure 1}

Proportion of High School Cheaters by Service Academy and Cohort

function of self-reported own high school cheating, the high school cheating of one's cohorts, and other exogenous variables. High school cheating is presumed to be exogenous with respect to academic cheating while enrolled at a service academy by virtue of occurring prior to service academy enrollment. ${ }^{23}$ In the second approach, we identify an endogenous peer effect by specifying the frequency of college academic cheating as a function of peer college cheating and other own exogenous variables, including own high school cheating. We estimate this equation using two-stage least squares (2SLS) with peer high school cheating as the excluded instrument. This methodology allows us to use the pretreatment cheating characteristics of the group to identify how cheating behavior varies with the average cheating behavior of the peer group correcting for simultaneity or common shocks to the group. Absent a more refined, specific, and well-justified theoretical model, we cannot say whether peers affect own college cheating through simultaneous peer college cheating, or predetermined peer characteristics, or some combination of each. In the former specification, our reduced form coefficients represent the correlation of pretreatment peer characteristics on college cheating, whether the effect is direct or indirect through peer college cheating. In the latter specification, we restrict the entire peer effect to occur through peer college cheating. For ease of exposition, we refer to these approaches as an exogenous peer effect and an endogenous peer effect.

For the exogenous peer effect, we estimate reduced form equations with the following explanatory variables:

23. One notable weakness in our data is that high school and college cheating are both self-reported, which may not be exogenous. Although there is no direct way to test this assertion, given the seriousness of the honor codes and the vast amount of honor education given to students at the service academies, we do not believe this to be a problem. 
Table 2

Own High School Cheating Regressed on Peer High School Cheating

\begin{tabular}{lcccc} 
Cohorts/ & & & & \\
Specification & $1-11$ & $1-4$ & $5-11$ & Controls \\
\hline 1 & $0.500^{* * *}$ & $0.663^{* * *}$ & 0.306 & Year \\
& $(0.108)$ & $(0.110)$ & $(0.180)$ & \\
2 & 0.265 & 0.148 & -0.229 & Year, academy \\
& $(0.185)$ & $(0.276)$ & $(0.301)$ & time trends \\
3 & -0.395 & $-1.174^{*}$ & -0.448 & Year, academy time \\
& $(0.281)$ & $(0.624)$ & $(0.382)$ & trends, academy \\
Observations & 2,060 & 803 & 1,257 & \\
\hline
\end{tabular}

Notes: * Significant at the 0.10 level, ** Significant at the 0.05 level, *** Significant at the 0.01 level. Robust standard errors in parentheses are clustered by class by academy.

$$
\begin{aligned}
\text { CollegeCheat }_{a y i}= & \beta_{0 a y}+\beta_{1} \text { HSCheat }_{a y i}+\beta_{2} \text { HSCheat }_{a y-i}+\beta_{3} \text { SAT }_{a y} \\
& +\beta_{4} O M_{a y i}+\varphi_{a}+\gamma_{y}+\phi_{a} y+\varepsilon_{a y i}
\end{aligned}
$$

where College Cheat $t_{a y i}$ is the frequency with which respondent $i$ at academy $a$ in cohort $y$ violated academic aspects of the honor code as a cadet/midshipman (see Q.15 in Appendix 2). HSCheat ayi $_{\text {is }}$ an indicator variable of whether respondent $i$ committed acts of academic cheating while in high school (see Q.16 in Appendix 2). HSCheat $_{a y-i}$ is the proportion of peers other than respondent $i$ who cheated while in high school. $\beta_{2}$, the main coefficient of interest in this specification, measures the effect of peer honesty (or peer effect) on each individual's decision to cheat. $S A T_{a y}$ is the 25th percentile SAT math score for the academy by graduating class population cohort. ${ }^{24} O M_{\text {ayi }}$ is the quartile order of merit the respondent graduated in (see Q.4 in Appendix 2). Our models employ service academy fixed effects $\left(\varphi_{a}\right)$, time (graduation class cohort) fixed effects $\left(\gamma_{y}\right)$, and academy specific linear time trends $\left(\phi_{a}\right)$. The fixed effects and linear time trends are used to control for all unobserved differences across academies and time, isolating the effects on academic cheating from changes in the within-academy/cohort peer variable. Given the potential for error correlation across individuals and across time within a given service academy and cohort, we correct all standard errors to reflect clustering at the academy by graduation-cohort level.

In accordance with economic theory and the works cited in the scholarly literature, we expect the following signs on estimated coefficients. If a pattern of academic cheating were established in high school, we would expect a higher likelihood of

24. SAT scores obtained from the College Board. This data only exists as far back as 1971, with some years missing between 1971 and 1981. 
cheating while enrolled at a service academy. Hence, we expect $\beta_{1}$ to be positive. In the language of Manski (1993), $\beta_{2}$ represents an exogenous peer effect. If positive, as we expect it to be, this would be consistent with peers influencing individual behavior and hence, cadets/midshipmen are more likely to behave honorably when their compatriots are more honest.

We expect that $\beta_{3}$, the coefficient on the 25th percentile SAT math score for the academy by graduating class population cohort, should be negative, as cohorts with higher levels of aptitude, all else equal, should exhibit lower levels of cheating. Finally, $\beta_{4}$, the coefficient on the order of merit variable should be positively correlated with cheating. Cadets/midshipmen who finish in the upper quartile within their class should have less incentive to cheat compared to those finishing in a lower quartile. ${ }^{25}$ Due to the potential endogeneity of this variable, we estimated our models with and without the inclusion of this variable.

To estimate an endogenous peer effect on cheating, we measure the direct effect of peer-college cheating on an individual's decision to cheat assuming that exogenous peer characteristics do not directly affect own cheating. We estimate models in various functional forms of Equation 2.

$$
\begin{aligned}
\text { CollegeCheat }_{a y i}= & \alpha_{0 a y}+\alpha_{1} \text { HSCheat }_{a y i}+\alpha_{2} \text { CollegeCheat }_{a y-i}+\alpha_{3} \text { SAT }_{a y} \\
& +\alpha_{4} \text { OM }_{a y i}+\varphi_{a}+\gamma_{y}+\phi_{a} y+\omega_{a y i}
\end{aligned}
$$

where College $\widehat{C}_{\text {heat }}{ }_{a y-i}$ is the predicted proportion of peer college cheaters for respondent $i$ at academy $a$ in cohort $y$. A priori, we expect to find estimated coefficients of the same signs as in the previous reduced form specification.

\section{Results}

Tables 3-6 present results of our analysis. Tables 3 and 4 show results for the reduced form linear probability model, which predicts the probability that an individual is a college cheater. The 2SLS model is shown in Table 5. Table 6 presents results for an analysis on reporting and tolerance of suspected cheating to examine the mechanisms that may influence peer cheating behavior. All specifications include service academy fixed effects and all standard errors are clustered by academy by graduating class cohort.

\section{A. Reduced Form Results for Exogenous Peer Effect}

Table 3, Specification 1 estimates the basic model, while excluding the potentially endogenous variable, graduation order of merit. The positive and significant coefficient (0.132) for the High School Cheater (dummy) variable indicates that high school cheaters have a 13.2 percentage point higher probability of cheating while in college. The estimated coefficient on the peer variable is positive and significant (0.342). The estimated effect of peer high school cheating on the frequency of

25. Alternatively, better grades could be the result of more aggressive cheating. We believe this to be less likely than our previous argument. 


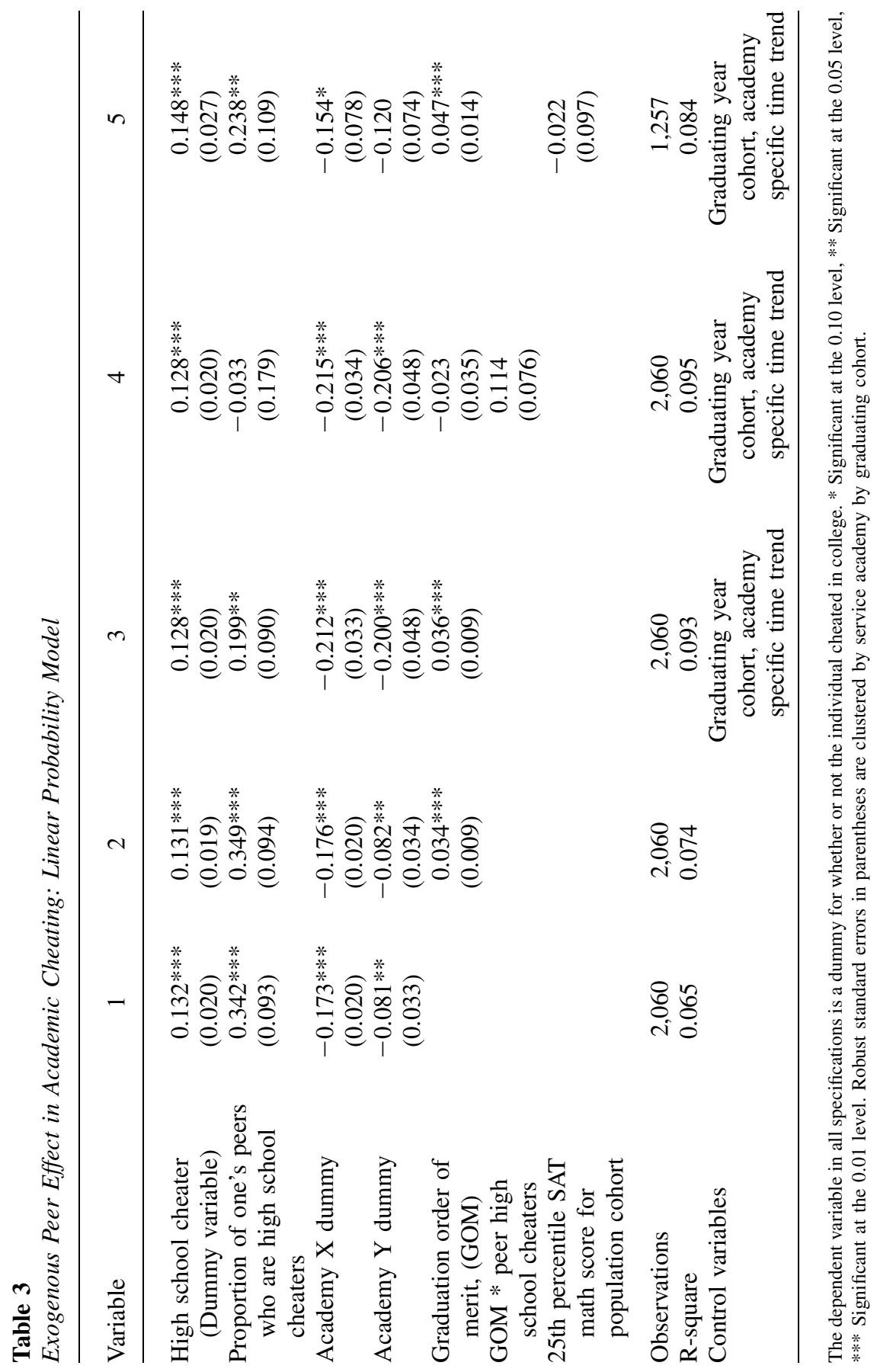




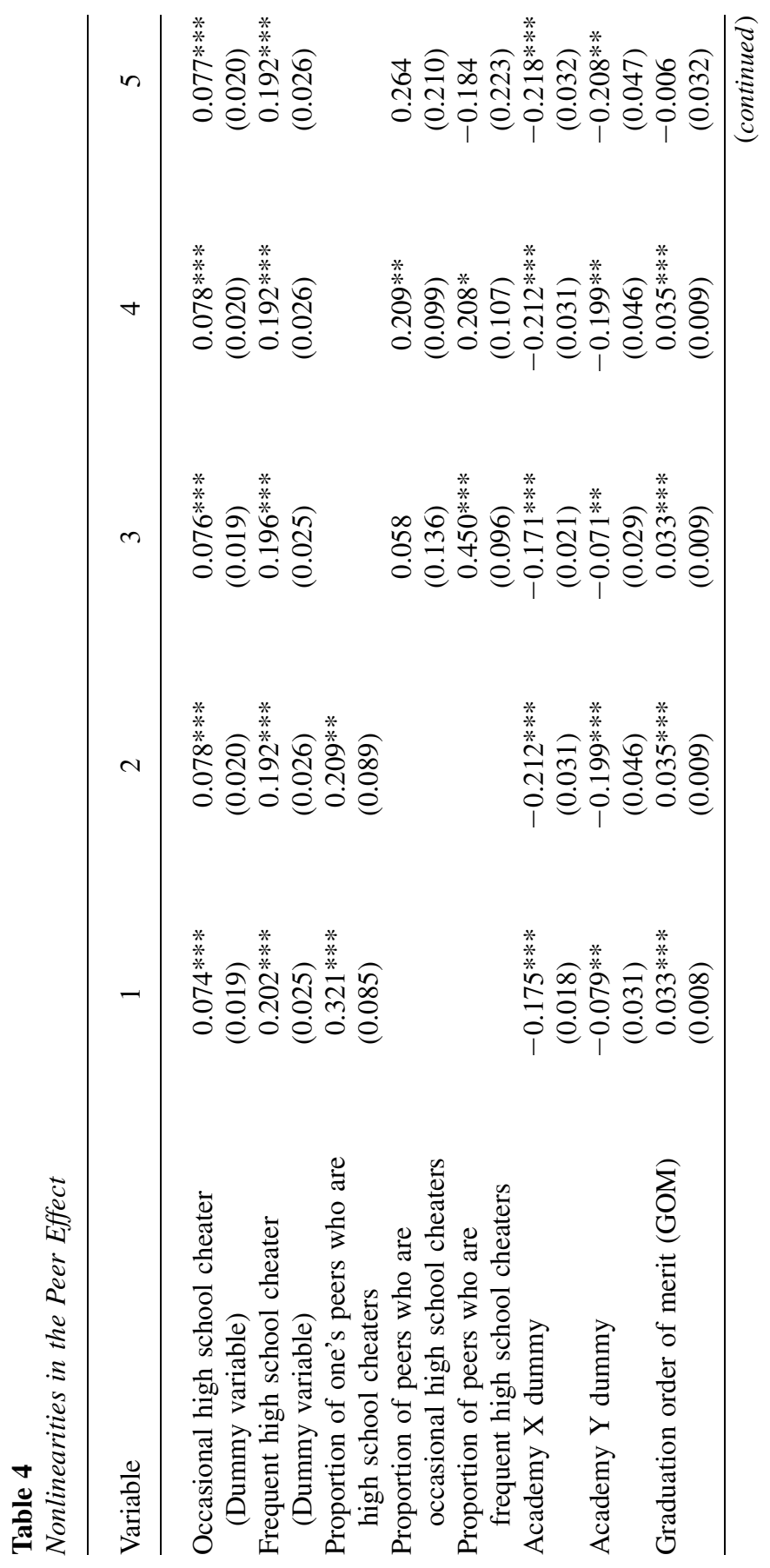




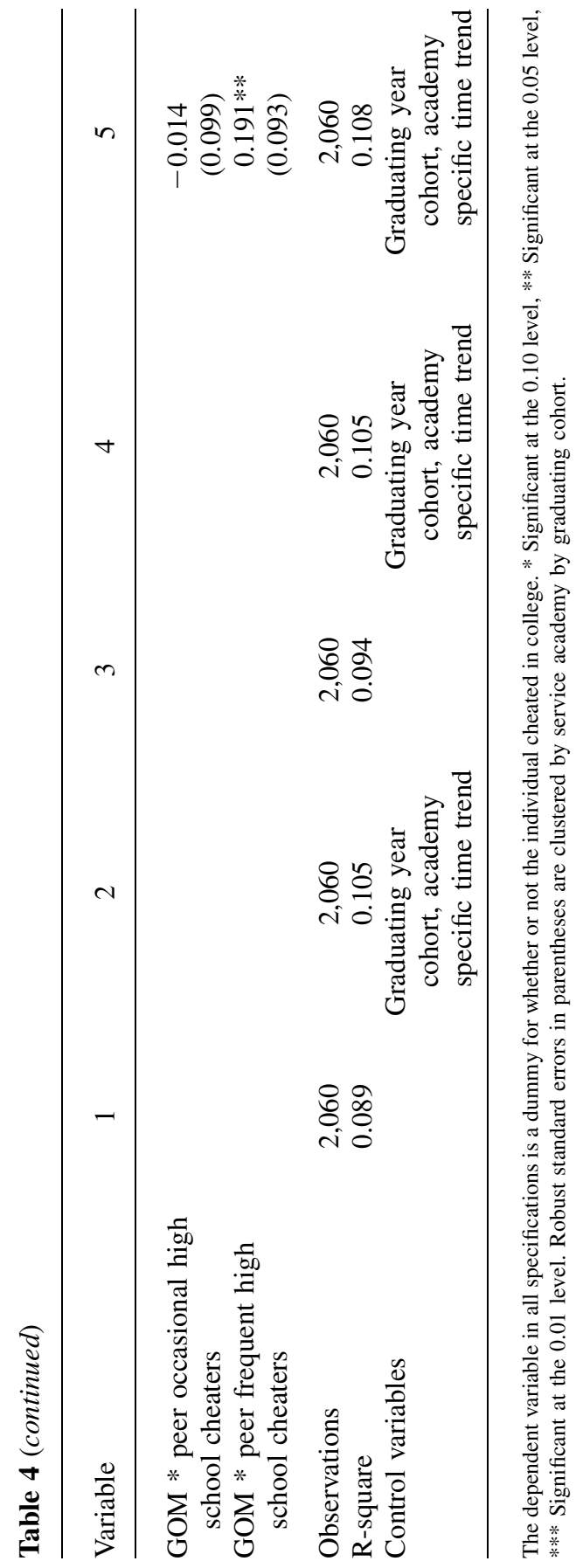




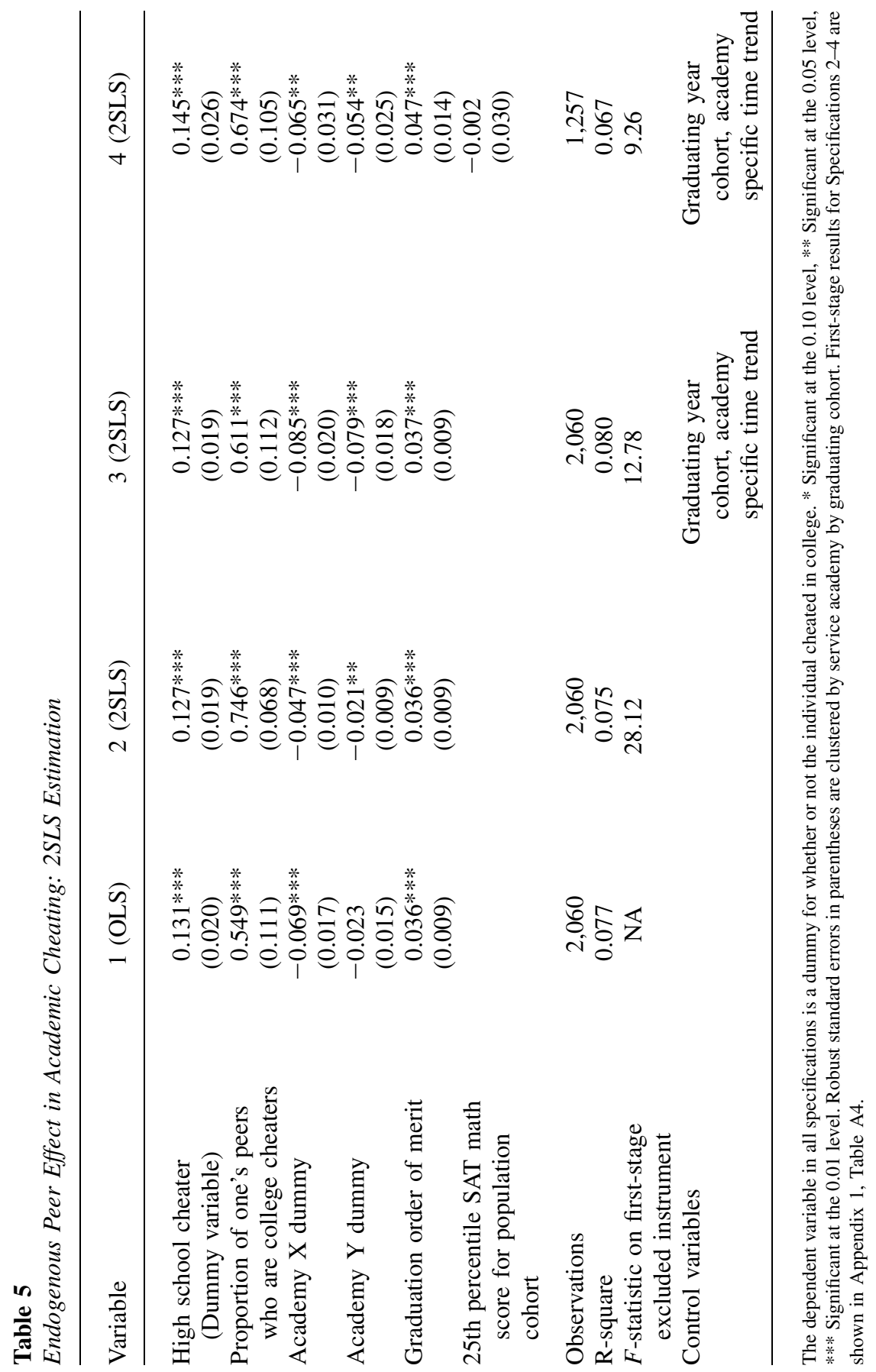




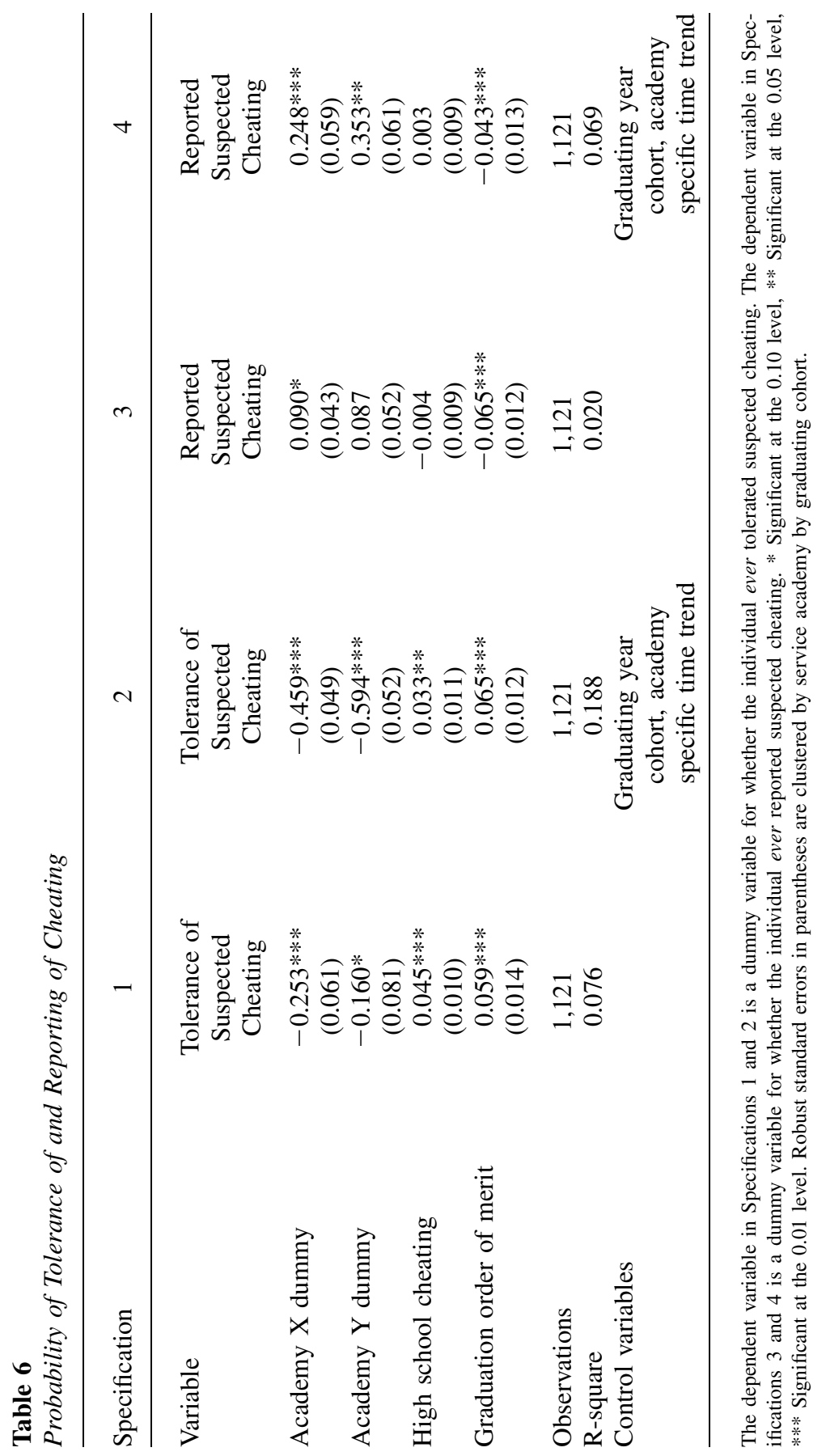


college cheating is substantial, with the admittance of one more high school cheater having the net estimated effect of producing 0.47 additional college cheaters. ${ }^{26}$ That is, for every 2.11 new high school cheaters admitted to a service academy, one additional college cheater will be "created." Following Glaeser, Sacerdote, and Scheinkman (2003), we believe this estimate to be the first-order effect and a lower bound of the total social influence. In full equilibrium, the creation of new cheaters is likely to create additional new cheaters, implying the existence of an endogenous "social multiplier." 27 Significant differences in the level of cheating are shown between the three service academies. ${ }^{28}$ The negative and significant result for the Academy $\mathrm{X}$ and Academy Y dummy variables indicates less cheating at these academies compared to Academy $\mathrm{Z}^{29}$

In Specification 2, we add the graduation order of merit (GOM) of the surveyed respondent as an explanatory variable. Results for this specification remain consistent with Specification 1, while the order of merit variable is positive and significant (0.034). This result indicates that cadets/midshipmen who perform better academically are less likely to cheat. ${ }^{30}$

If the peer variable is correlated with unobserved serial factors or with timespecific trends in cheating within each academy, the previously presented results could be spurious. To control for this possibility, we add time (graduation year cohort) fixed effects and academy-specific linear time trends to the model in Specification 3. Results remain statistically significant for the peer effect, with all variables of the expected signs. The positive and significant result for both the high school cheater variable (0.128) and the peer variable (0.199) indicate that one additional cheater is created for every 3.06 new cheaters admitted to a service academy.

Due to the binary nature and uniqueness of our dependent variable, it is difficult to compare directly the magnitude of the peer effect relative to other existing higher education studies. For Specification 3, a one standard-deviation increase in the peer high school cheating variable results in a 0.03 or one-fourteenth of a standard-deviation increase in the dependent variable. This compares to Sacerdote (2001), who finds a one standard-deviation increase in roommate GPA increases individual GPA by 0.05 grade points or one-eighth of a standard deviation.

A more direct comparison of our estimated peer effect (0.199 in Specification 3) can be made to Bayer, Pintoff, and Pozen (2005) who estimate criminal recidivism peer effects of $0.13,0.14,0.23$, and 0.29 for the proportion of peers who were convicted of burglary, petty larceny, misdemeanor drug, and felony sex, respectively. ${ }^{31}$ Hence,

26. This effect is calculated by adding the coefficients on the High School Cheater and the Peer variables. 27. Empirical estimation of the social multiplier is discussed extensively in Glaeser, Sacerdote, and Scheinkman (2003). We estimate the social multiplier and discuss its estimation later in the text.

28. The names of the three service academies have been masked and are referred to as Academy X, Academy Y, and Academy Z.

29. The coefficients on Academy X and Academy Y dummy variables are also statistically different at the 0.01-level.

30. The GOM variable is entered linearly for each quartile of the order of merit. We also tested the model while including each quartile of the order of merit separately as dummy variables. The $F$-statistic on the restriction is insignificant, indicating that the linearity assumption is valid.

31. One notable difference between our estimates and those of Bayer, Pintoff, and Pozen (2005) is the latter peer effects are that of a reinforcing nature. That is, the peer effect for burglary is estimated for individuals who have been previously arrested for burglary. 
these "bad behavior" peer effects estimates are similar in magnitude and statistically indistinguishable for juvenile criminals and military academy college students.

In Specification 4, we add an interaction term between the peer variable and the GOM variable to determine if individuals with varying academic outcomes are affected differently by peer influence. The positive coefficient $(0.114)$ for the interaction term indicates that the peer influence is greater for individuals in lower quartiles of the GOM; however, the coefficient is not statistically significant at any conventional level.

Finally, we add the 25th percentile SAT math score for the academy by graduating class population cohort in Specification 5. Due to data availability, this specification only includes the final seven cohorts in the sample. Results show that the magnitudes of the High School Cheater variable (0.148) and the peer effect $(0.238)$ increase relative to the previous specification. The coefficient on the SAT variable has the expected negative sign but is statistically insignificant.

\section{B. Nonlinearities in the Peer Effect}

We report in Table 4 the results of additional specifications allowing for different marginal effects of frequent versus occasional high school cheaters. Specifications 1 and 2 exploit the categorical data available in the High School Cheater variable by adding separate dummy variables for occasional high school cheaters and frequent high school cheaters. ${ }^{32}$ Specification 1 includes service academy dummy variables, while Specification 2 includes the time fixed effect and the academy-specific linear time trends. The positive and significant results for both High School Cheater variables (in both specifications) indicate that occasional and frequent high school cheaters are both more likely to cheat in college when compared to noncheaters. The probability of cheating in college for frequent high school cheaters is roughly double that of one-time high school cheaters, with the difference in coefficients statistically significant at the 0.01 -level. In both specifications, the peer effect is positive and significant with the magnitude consistent with the previous results.

We add separate peer variables in Specifications 3 and 4 for the proportion of one's peers who were occasional and frequent high school cheaters. Again, results show statistically significant differences in college cheating between high school noncheaters, occasional cheaters, and frequent cheaters. Results for Specification 3 show significant differences between the magnitudes of the two peer variables. The occasional cheater peer effect variable is positive and insignificant (0.058), while the frequent cheater peer effect variable is positive and highly significant $(0.450)$, with the difference in the two coefficients significant at the 0.01-level. This result provides some evidence of nonlinearity in the peer effect across high school cheater types. The model predicts that 1.55 additional frequent high school cheaters create one new college cheater. However, these differences are no longer evident in Specification 4, which includes the time fixed effects and linear time trends. Results for this specification show a positive and significant result for both peer variables $(0.209$ and 0.208 respectively) with no statistically significant difference in the coefficients.

32. An occasional high school cheater is defined as someone giving a number two response to Question 16 of the survey, indicating one to three total cheating incidents while in high school. A frequent high school cheater is defined as someone who reported cheating at least one to four times per year or greater. 
We add interaction terms between the peer variables and the graduation order of merit variable in Specification 5 to test for nonlinearities in the peer effect across the levels of academic aptitude. The positive and statistically significant coefficient (0.191) for the interaction term with the peer frequent high school cheater variable indicates that the peer effects are stronger for individuals in the lower quartiles of the GOM. Estimates of the peer effect for each quartile of the GOM are $0.08,0.20,0.39$, and 0.58 respectively, with the coefficients statistically significant for all quartiles except for quartile one.

\section{2SLS Results for Endogenous Peer Effect}

We present results for the 2SLS estimations of college cheating as a function of peer college cheating as specified in Equation 2 in Table 5. ${ }^{33}$ As with the previous results, we believe these estimates to be a lower bound of the total social influence. The social multiplier, an upper bound of the total social influence, is calculated in the next section. For purely comparative purposes, Specification 1 presents the OLS estimate of the endogenous peer college cheating variable which is positive $(0.549)$ and statistically significant. In Specifications 2 and 3, the (endogenous) peer effect exhibits the expected sign and is highly significant and all other coefficients in the model are consistent with the results presented in the reduced form estimates. For Specification 2, the estimated peer coefficient (0.746) indicates that for every 1.34 new college cheaters added to a service academy, one additional college student will cheat. We add the graduating class cohort fixed effect and the academy specific linear time trends to the model in Specification 3 and the 25th percentile SAT Math Score in Specification 4. The magnitude of the peer effect remains positive and highly significant in both specifications with a small decrease in the magnitude of the effects.

Results in Table 5, using 2SLS estimation, are consistent with those presented in the previous sections using OLS on reduced form equations. Together, these equations provide strong evidence of positive peer effects in academic cheating.

\section{The Social Multiplier}

Becker and Murphy (2000), Glaeser, Sacerdote, and Scheinkman (2003), and Graham (2006) and others discuss the existence and estimation of a social multiplier in the presence of positive spillovers or strategic complementarities. In the context of our paper, the social multiplier exists as newly created cheaters exert peer influence, which create yet more cheaters. Multiple rounds of expansion could occur as new cheaters beget more new cheaters. If infinite rounds of this process occurred, and the creation of partial cheaters were possible, the social multiplier would approach $1 /\left(1-\alpha_{2}\right)$ as group size grows large, where $\alpha_{2}$ is the estimated coefficient on peer college cheating, or the (endogenous) social interaction term. Estimates of the social multiplier using Specifications 2 and 3 in Table 5 are 3.93 and 2.57, respectively. Hence, in full equilibrium, our models estimate the addition of one college cheater "creates" roughly three new college cheaters.

Glaeser, Sacerdote, and Scheinkman (2003) provide an alternative approach for estimating the social multiplier in which the group level coefficient is divided by

33. First-stage results are shown in Appendix 1, Table A4 where Peer College Cheating is regressed on Peer HS occasional and frequent cheaters and the remaining exogenous variables. 
the individual level coefficient. This methodology is implemented using the coefficients on exogenous variables, when the endogenous social interaction term cannot be directly estimated. Using this methodology, we compute the social multiplier using the ratio of the coefficients for the high school cheater variable. With comparable control variables to Specifications 2 and 3 in Table 3, we compute social multipliers of 3.05 and 2.59 respectively.

Our estimates of the social multiplier are in line with those estimated by Glaeser, Sacerdote, and Scheinkman (2003) and Graham (2006). In using Dartmouth roommate data, the social multiplier for fraternity membership approaches 2.8 as group size grows large. For crime data, estimates of the social multiplier at the county, state, and national-level, were 1.72, 2.8, and 8.16 respectively. Graham (2006) estimates a social multiplier of 1.86 and 2.30 in elementary school math and reading using data from project STAR.

\section{E. Mechanisms Driving the Peer Effect}

Having found statistical evidence of peer effects in academic cheating at service academies, we turn our attention to an inquiry into possible mechanisms that could drive peer effects. Academic cheating could be viewed in the context of an enforcement problem where the rising level of academic cheating could be seen as evidence of a congestion problem in enforcement activity. Alternatively, peer effects could represent changing or different social norms regarding tolerance of cheating. To investigate this further, we examine differences across the service academies in the attitudes and actions regarding peers violating the honor code. McCabe, Trevino and Butterfield (2001) hypothesize that (1) "Peer reporting behavior will increase as role responsibility for peer reporting increases," (2) "Increased role responsibility for peer reporting will be positively associated with the perception that cheaters will be caught," and (3) "Cheating will be lower where there is a stronger perception that cheaters will be caught."

Given their hypotheses, we examine whether peer reporting of suspected violations is in fact greatest at Academies $\mathrm{X}$ and $\mathrm{Y}$ with lower amounts of cheating. We also examine whether tolerance of known cheating is different across the three academies. Although one would think that peer reporting and tolerance of known cheating would be inversely correlated, we find individuals in our data set who indicated that they knew of, but did not report, others violating the honor code, yet also reported others who were violating the honor code (see Q.8 and Q.11, Appendix 2). Our survey did not ask for the precise circumstances under which this happened, but we find it of interest that a number of individuals both tolerated and turned in violations of the honor code.

Specifications 1 and 2 in Table 6 predict the probability of tolerance of cheating, conditional on having knowledge of suspected cheating. Results from both specifications show that both graduation order of merit and the level of high school cheating are strong predictors of tolerance. Note that the negative and significant estimated coefficients for the Academy $\mathrm{X}$ and $\mathrm{Y}$ variables indicate that these academies have less tolerance of cheating, compared to Academy Z. ${ }^{34}$

34. The coefficients on the Academy X and Academy Y dummy variables are not statistically different from each other in both specifications. 
Specifications 3 and 4 predict the probability of reporting cheating, given knowledge of suspected cheating. Results in both specifications indicate that graduation order of merit is a good predictor of reporting, but the coefficient on high school cheating is insignificant in both specifications and opposite the a-priori expected sign in Specification 3. In addition, the positive and significant results for the Academy $X$ and Academy Y dummy variables in Specification 4, with cohort fixed effects and linear time trends, show that reporting is greater at Academy $\mathrm{X}$ and Academy $\mathrm{Y}$ compared to Academy $\mathrm{Z}$.

The results in Table 6 show that, conditional on knowledge of suspected cheating, cadets/midshipman at Academy $\mathrm{X}$ and Academy $\mathrm{Y}$ are more likely to report and less likely to tolerate cheating. In previous analysis, we showed these academies to have the lowest probability of cheating. We find this to be evidence that the peer effect is that of an evolving social norm in cheating versus congestion in enforcement. This result follows McCabe and Trevino's (1993) hypothesis that "Academic dishonesty will be inversely related to the perceived certainty of being reported by a peer."

\section{Conclusion}

This paper investigates peer influence in academic cheating using survey data gathered from the United States Military Academy, the United States Naval Academy, and the United States Air Force Academy from 1959 through 2002. We measure the effects on individual cheating from changes in the honesty of peers. Our results provide evidence of large positive peer effects in academic cheating. The models predict that one new college cheater is "created" for every two to three additional high school cheaters admitted to a service academy.

We find different magnitudes of peer effects from occasional versus frequent cheaters. The academies with the lowest levels of cheating have the highest level of peer reporting of violations. We find this consistent with peer effects in academic cheating being an evolving social norm of tolerance as opposed to congestion in enforcement.

We realize the educational experience for students at the military academies is different from most traditional colleges and universities, which draws into question the generalizability of our results to the population of American college students. Because students at military academies are taught to foster teamwork, our peer effects estimates could be larger than those expected at other institutions. Military academy students are evaluated on leadership aptitude. Peers may exert less influence over stronger leaders. If true, other institutional settings could exhibit larger peer effects in academic cheating. Nevertheless, our results indicate that policies that promote peer enforcement of suspected cheating may help reduce the incidence of cheating on college campuses. Reduced cheating would in turn strengthen the credibility of a university education as a signal in the labor market.

\section{Appendix 1}

\section{Supplemental Regressions}




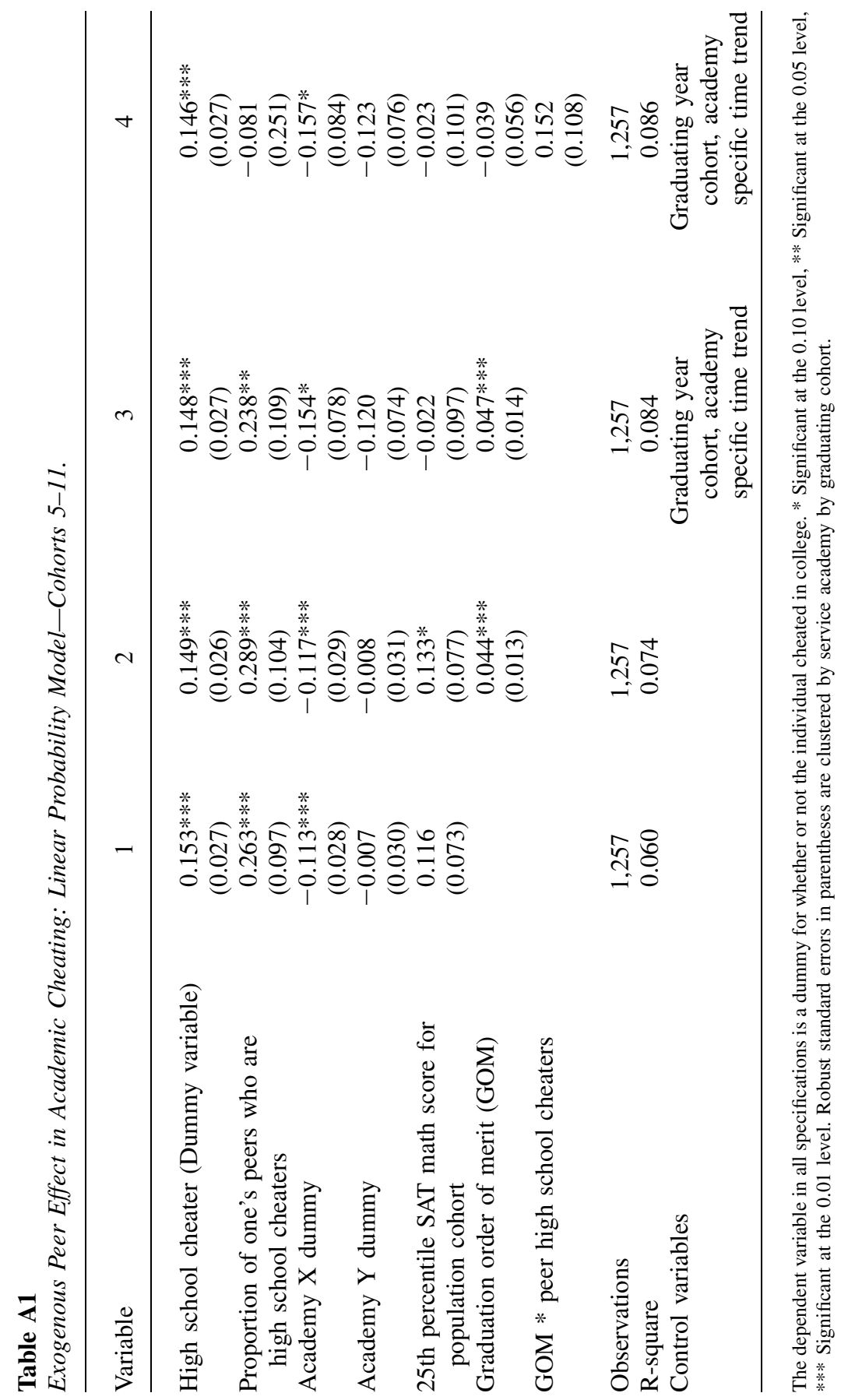




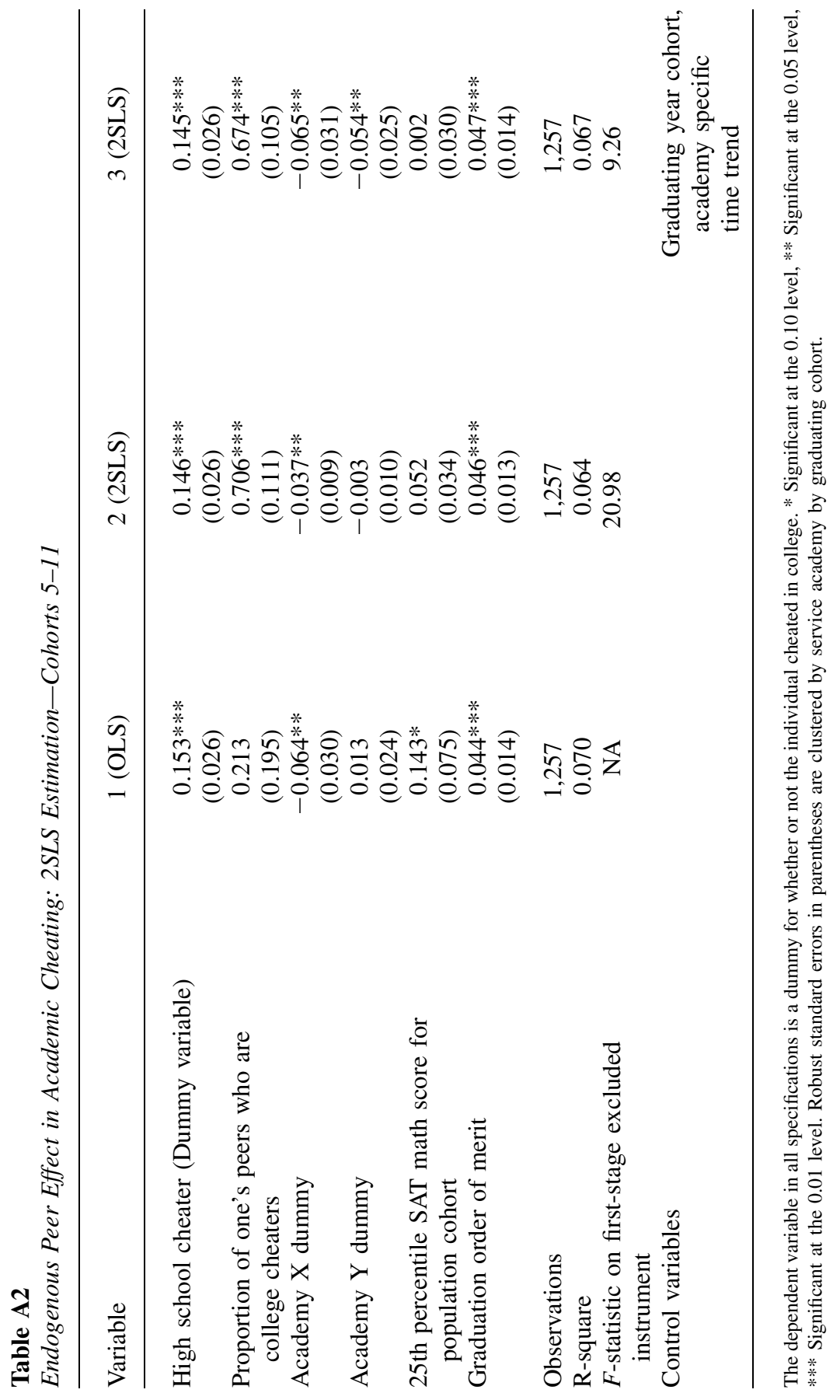




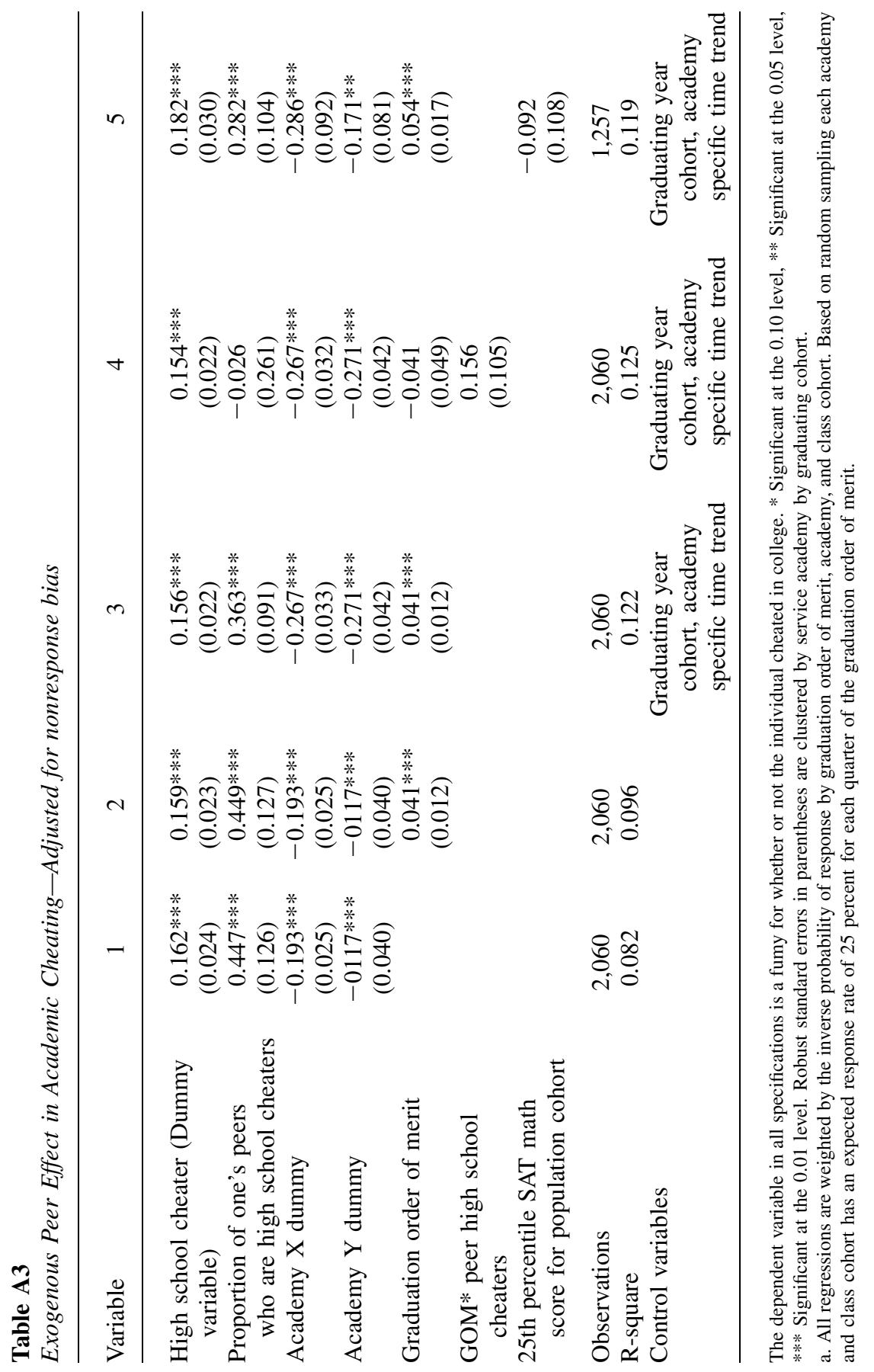




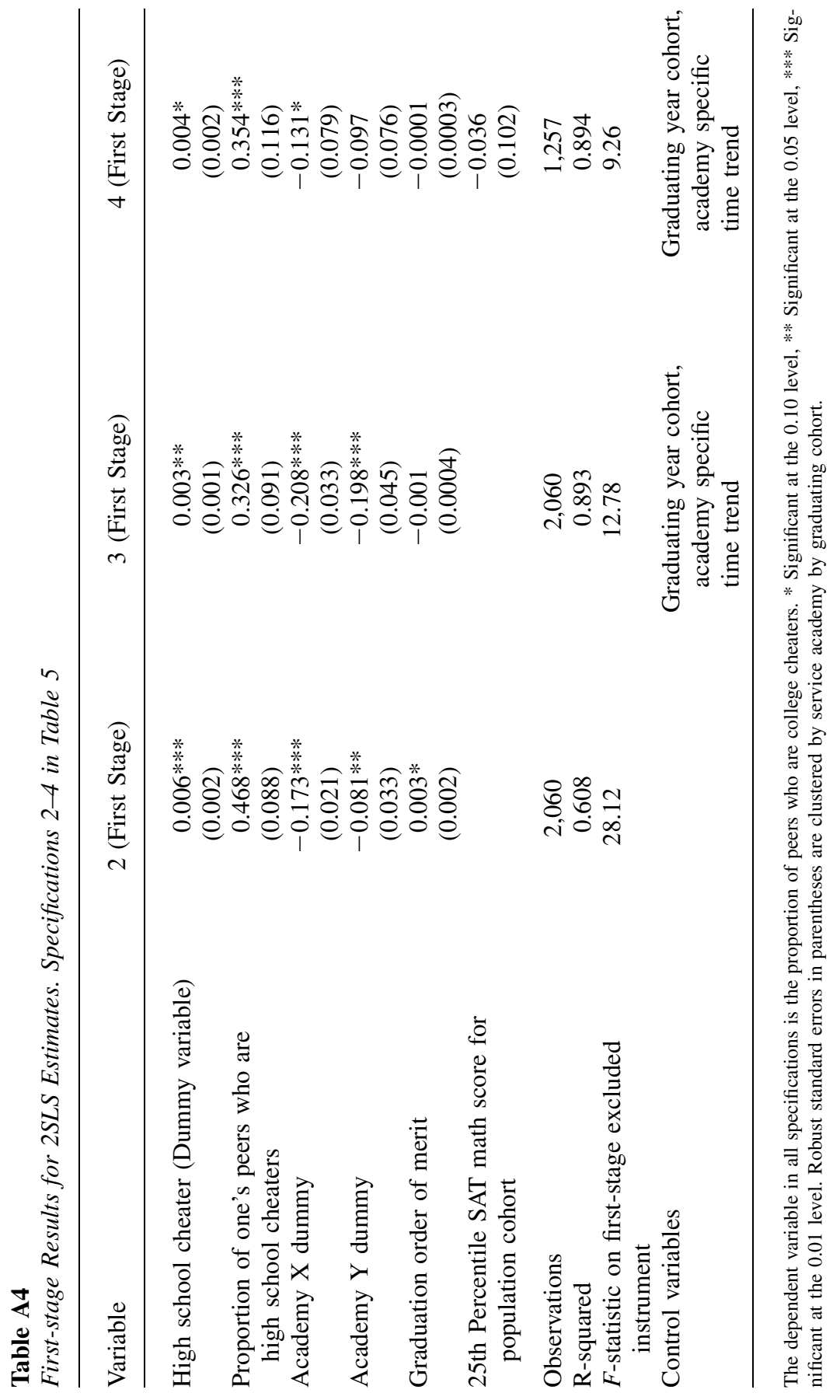




\section{Appendix 2}

Honor Survey

\section{PART I. DEMOGRAPHICS}

\section{Please Circle Whichever Applies to You.}

1. I graduated from:
a. USMA
b. USNA
c. USAFA

2. In the class of:
a. $1959,60,61$, or 62
b. $1963,64,65$, or 66
c. $1967,68,69$, or 70
d. $1971,72,73$, or 74
e. $1975,76,77$, or 78
f. $1979,80,81$, or 82
g. $1983,84,85$, or 86
h. $1987,88,89$, or 90
i. $1991,92,93$, or 94
j. $1995,96,97$, or 98
k. $1999,00,01$, or 02

3. My current military status is: (Please disregard any Reserve or National Guard Status)
a. I am still on active duty.
b. I voluntarily resigned from the service.
c. I voluntarily retired from the service.
d. Other (medical retirement, not commissioned, etc.)

4. My graduation order of merit was:
a. Top $1 / 4$
b. Second $1 / 4$
c. Third $1 / 4$
d. Fourth $1 / 4$ 


\section{PART II. QUESTIONNAIRE.}

Please Circle Whichever You Feel Applies. If You Prefer Not to Answer Any Question, Just Leave it Blank.

5. As a cadet/midshipman, my respect for the honor code was:

\begin{tabular}{lcccccc}
1 & 2 & 3 & 4 & 5 & 6 & 7 \\
\hline $\begin{array}{l}\text { totally } \\
\text { negative }\end{array}$ & $\begin{array}{l}\text { strongly } \\
\text { negative }\end{array}$ & $\begin{array}{c}\text { mildly } \\
\text { negative }\end{array}$ & neutral & $\begin{array}{l}\text { mildly } \\
\text { positive }\end{array}$ & $\begin{array}{l}\text { strongly } \\
\text { positive }\end{array}$ & $\begin{array}{l}\text { totally } \\
\text { positive }\end{array}$
\end{tabular}

6. As a cadet/midshipman, my motivation to make the service a career was:

\begin{tabular}{|c|c|c|c|c|c|c|}
\hline 1 & 2 & 3 & 4 & 5 & 6 & 7 \\
\hline $\begin{array}{l}\text { never } \\
\text { intended } \\
\text { to stay }\end{array}$ & $\begin{array}{l}\text { strongly } \\
\text { non } \\
\text { career }\end{array}$ & $\begin{array}{l}\text { mildly } \\
\text { non } \\
\text { career }\end{array}$ & $\begin{array}{l}\text { neutral } \\
\text { wait } \\
\text { and see }\end{array}$ & $\begin{array}{l}\text { mildly } \\
\text { pro- } \\
\text { career }\end{array}$ & $\begin{array}{l}\text { strongly } \\
\text { pro- } \\
\text { career }\end{array}$ & $\begin{array}{l}\text { totally } \\
\text { intended } \\
\text { a career }\end{array}$ \\
\hline
\end{tabular}

7. As a cadet/midshipman, I suspected (but could not confirm) other cadets/midshipmen of violating the honor code:

\begin{tabular}{|c|c|c|c|c|c|c|}
\hline 1 & 2 & 3 & 4 & 5 & 6 & 7 \\
\hline never & $\begin{array}{l}1-3 \\
\text { times } \\
\text { total }\end{array}$ & $\begin{array}{l}1-4 \\
\text { times } \\
\text { a year }\end{array}$ & $\begin{array}{ll}\text { occasionally } & \text { about } \\
\text { every } & \text { few } \\
\text { months } & \text { a month }\end{array}$ & $\begin{array}{l}2-3 \\
\text { once }\end{array}$ & $\begin{array}{l}\text { routinely } \\
\text { times } \\
\text { a month or daily }\end{array}$ & weekly \\
\hline
\end{tabular}

8. As a cadet/midshipman, I knew of (but did not report) other cadets/midshipmen who were violating the honor code:

\begin{tabular}{|c|c|c|c|c|c|c|}
\hline 1 & 2 & 3 & 4 & 5 & 6 & 7 \\
\hline never & $\begin{array}{l}1-3 \\
\text { times } \\
\text { total }\end{array}$ & $\begin{array}{l}1-4 \\
\text { times } \\
\text { a year }\end{array}$ & $\begin{array}{ll}\text { occasionally about } \\
\text { every } & \text { few } \\
\text { months } & \text { a month }\end{array}$ & $\begin{array}{l}2-3 \\
\text { once } \\
\text { a month }\end{array}$ & $\begin{array}{l}\text { routinely } \\
\text { times } \\
\text { or daily }\end{array}$ & weekly \\
\hline
\end{tabular}

9. As a cadet/midshipman, I wanted to (but did not) report violations of the honor code:

\begin{tabular}{|c|c|c|c|c|c|c|}
\hline 1 & 2 & 3 & 4 & 5 & 6 & 7 \\
\hline never & $\begin{array}{l}1-3 \\
\text { times } \\
\text { total }\end{array}$ & $\begin{array}{l}1-4 \\
\text { times } \\
\text { a year }\end{array}$ & $\begin{array}{ll}\text { occasionally about } \\
\text { every } & \text { few } \\
\text { months } & \text { a month }\end{array}$ & $\begin{array}{l}2-3 \\
\text { once } \\
\text { a month }\end{array}$ & $\begin{array}{l}\text { routinely } \\
\text { times } \\
\text { or daily }\end{array}$ & weekly \\
\hline
\end{tabular}


10. As a cadet/midshipman, I confronted other cadets/midshipmen who I felt had violated the honor code:

\begin{tabular}{|c|c|c|c|c|c|c|}
\hline 1 & 2 & 3 & 4 & 5 & 6 & 7 \\
\hline never & $\begin{array}{l}1-3 \\
\text { times } \\
\text { total }\end{array}$ & $\begin{array}{l}1-4 \\
\text { times } \\
\text { a year }\end{array}$ & $\begin{array}{ll}\text { occasionally about } \\
\text { every } & \text { few } \\
\text { months } & \text { a month }\end{array}$ & $\begin{array}{l}2-3 \\
\text { once } \\
\text { a month }\end{array}$ & $\begin{array}{l}\text { routinely } \\
\text { times } \\
\text { or daily }\end{array}$ & weekly \\
\hline
\end{tabular}

11. As a cadet/midshipman, I reported other cadets/midshipmen who I felt had violated the honor code:

\begin{tabular}{|c|c|c|c|c|c|c|}
\hline 1 & 2 & 3 & 4 & 5 & 6 & 7 \\
\hline never & $\begin{array}{l}1-3 \\
\text { times } \\
\text { total }\end{array}$ & $\begin{array}{l}1-4 \\
\text { times } \\
\text { a year }\end{array}$ & $\begin{array}{ll}\text { occasionally about } \\
\text { every } & \text { few } \\
\text { months } & \text { a month }\end{array}$ & $\begin{array}{l}2-3 \\
\text { once } \\
\text { a month }\end{array}$ & $\begin{array}{l}\text { routinely } \\
\text { times } \\
\text { or daily }\end{array}$ & weekly \\
\hline
\end{tabular}

12. As a cadet/midshipman, I received (but did not actively seek out) academic information in violation of the honor code:

\begin{tabular}{|c|c|c|c|c|c|c|}
\hline 1 & 2 & 3 & 4 & 5 & 6 & 7 \\
\hline never & $\begin{array}{l}1-3 \\
\text { times } \\
\text { total }\end{array}$ & $\begin{array}{l}1-4 \\
\text { times } \\
\text { a year }\end{array}$ & $\begin{array}{ll}\text { occasionally about } \\
\text { every } & \text { few } \\
\text { months } & \text { a month }\end{array}$ & $\begin{array}{l}2-3 \\
\text { once } \\
\text { a month }\end{array}$ & $\begin{array}{l}\text { routinely } \\
\text { times } \\
\text { or daily }\end{array}$ & weekly \\
\hline
\end{tabular}

13. As a cadet/midshipman, I was actively involved in either receiving or passing academic information in violation of the honor code:

\begin{tabular}{|c|c|c|c|c|c|c|}
\hline 1 & 2 & 3 & 4 & 5 & 6 & 7 \\
\hline never & $\begin{array}{l}1-3 \\
\text { times } \\
\text { total }\end{array}$ & $\begin{array}{l}1-4 \\
\text { times } \\
\text { a year }\end{array}$ & $\begin{array}{ll}\text { occasionally about } \\
\text { every } & \text { few } \\
\text { months } & \text { a month }\end{array}$ & $\begin{array}{l}2-3 \\
\text { once } \\
\text { a month }\end{array}$ & $\begin{array}{l}\text { routinely } \\
\text { times } \\
\text { or daily }\end{array}$ & weekly \\
\hline
\end{tabular}

14. As a cadet/midshipman, I felt I had violated some NONacademic aspect of the honor code:

\begin{tabular}{|c|c|c|c|c|c|c|}
\hline 1 & 2 & 3 & 4 & 5 & 6 & 7 \\
\hline never & $\begin{array}{l}1-3 \\
\text { times } \\
\text { total }\end{array}$ & $\begin{array}{l}1-4 \\
\text { times } \\
\text { a year }\end{array}$ & $\begin{array}{ll}\text { occasionally about } \\
\text { every } & \text { few } \\
\text { months } & \text { a month }\end{array}$ & $\begin{array}{l}2-3 \\
\text { once } \\
\text { a month }\end{array}$ & $\begin{array}{l}\text { routinely } \\
\text { times } \\
\text { or daily }\end{array}$ & weekly \\
\hline
\end{tabular}


15. As a cadet/midshipman, I felt I had violated some academic aspect of the honor code:

\begin{tabular}{|c|c|c|c|c|c|c|}
\hline 1 & 2 & 3 & 4 & 5 & 6 & 7 \\
\hline never & $\begin{array}{l}1-3 \\
\text { times } \\
\text { total }\end{array}$ & $\begin{array}{l}1-4 \\
\text { times } \\
\text { a year }\end{array}$ & $\begin{array}{ll}\text { occasionally about } \\
\text { every } & \text { few } \\
\text { months } & \text { a month }\end{array}$ & $\begin{array}{l}2-3 \\
\text { once } \\
\text { a month }\end{array}$ & $\begin{array}{l}\text { routinely } \\
\text { times } \\
\text { or daily }\end{array}$ & weekly \\
\hline
\end{tabular}

16. When I was in high school, I was actively involved in either receiving or passing academic information (activities which would otherwise have been academic violations of the academy honor code):

\begin{tabular}{|c|c|c|c|c|c|c|}
\hline 1 & 2 & 3 & 4 & 5 & 6 & 7 \\
\hline never & $\begin{array}{l}1-3 \\
\text { times } \\
\text { total }\end{array}$ & $\begin{array}{l}1-4 \\
\text { times } \\
\text { a year }\end{array}$ & $\begin{array}{ll}\text { occasionally about } \\
\text { every } & \text { few } \\
\text { months } & \text { a month }\end{array}$ & $\begin{array}{l}2-3 \\
\text { once } \\
\text { a month }\end{array}$ & $\begin{array}{l}\text { routinely } \\
\text { times } \\
\text { or daily }\end{array}$ & weekly \\
\hline
\end{tabular}

17. Today, my respect for the honor code is:

\begin{tabular}{lcccccc}
1 & 2 & 3 & 4 & 5 & 6 & 7 \\
\hline $\begin{array}{l}\text { totally } \\
\text { negative }\end{array}$ & $\begin{array}{l}\text { strongly } \\
\text { negative }\end{array}$ & $\begin{array}{l}\text { mildly } \\
\text { negative }\end{array}$ & neutral & $\begin{array}{l}\text { mildly } \\
\text { positive }\end{array}$ & $\begin{array}{l}\text { strongly } \\
\text { positive }\end{array}$ & $\begin{array}{l}\text { totally } \\
\text { positive }\end{array}$
\end{tabular}

18. Compared to civilian college and universities, I think today's service academy cadets/midshipmen are involved in academic cheating:

\begin{tabular}{llllccl}
1 & 2 & 3 & 4 & 5 & 6 & 7 \\
\hline $\begin{array}{l}\text { much } \\
\text { less }\end{array}$ & $\begin{array}{l}\text { less } \\
\text { than half } \\
{[<1 / 10]}\end{array}$ & $\begin{array}{l}\text { a bit } \\
\text { as much }\end{array}$ & $\begin{array}{l}\text { less } \\
\text { the same }\end{array}$ & $\begin{array}{l}\text { a bit } \\
\text { more }\end{array}$ & $\begin{array}{l}\text { about } \\
\text { twice }\end{array}$ & $\begin{array}{l}\text { much } \\
\text { more } \\
\text { as much }[>10 \mathrm{X}]\end{array}$
\end{tabular}

19. Of all those values I learned at the Academy, I rate these items (shown alphabetically below) to be of the following importance. Please rate using the number scale shown (ties are acceptable):

\begin{tabular}{llccccc}
1 & 2 & 3 & 4 & 5 & 6 & 7 \\
\hline $\begin{array}{l}\text { not at } \\
\text { all }\end{array}$ & $\begin{array}{l}\text { not } \\
\text { very }\end{array}$ & $\begin{array}{l}\text { at times } \\
\text { important }\end{array}$ & $\begin{array}{l}\text { moderately } \\
\text { important }\end{array}$ & $\begin{array}{l}\text { above } \\
\text { average }\end{array}$ & very & $\begin{array}{l}\text { extremely } \\
\text { important }\end{array}$
\end{tabular}


$\underline{\text { Rating: }}$

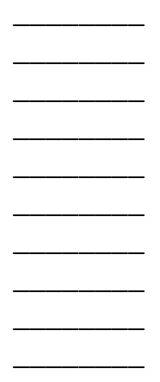

$\underline{\text { Topics Learned: }}$

a. Academics

b. Athletics

c. Confidence

d. Coping with pressure

e. Honor

f. Leadership

g. Loyalty

h. Self-discipline

i. Working with others

j. Other(s) [please specify]

20. My feelings about the honor code/concept today can be expressed as:

21. If, as a cadet/midshipman you feel you violated the honor code/concept, could you briefly describe those circumstances?

21. Do you have any other comments, suggestions, or questions? Many thanks for your cooperation.

Note: Questions 19-21 were included in a latter mailing to approximately half of the graduates surveyed. As a consequence, numerical data from question 19 was not included in our empirical analysis.

\section{References}

Bayer, Patrick, Randi Pintoff, and David E. Pozen. 2005. "Building Criminal Capital Behind Bars: Peer Effects in Juvenile Corrections." Center for Economic Growth Working Paper. New Haven: Yale University.

Besley, Timothy, and Anne Case. 1994. "Diffusion as a Learning Process: Evidence from HYV Cotton." Manuscript. Princeton, N.J.: Princeton University.

Becker, Gary S. 1962. "Investment in Human Capital: A Theoretical Analysis." Journal of Political Economy 70(2: Investment in Human Beings):9-49.

Becker, Gary S., and Kevin M. Murphy. 2000. Social Economics: Market Behavior in a Social Environment. Cambridge, Mass.: Harvard University Press.

Betts, Julian R., and Andrew Zau. 2004. "Peer Groups and Academic Achievement: Panel Evidence from Administrative Data." University of California, San Diego and Public Policy Institute of California Working Paper.

Boozer, Michael, and Stephen E. Cacciola. 2001. "Inside the 'Black Box' of Project STAR: Estimation of Peer Effects Using Experimental Data." Economic Growth Center Discussion Paper No. 832, Yale University. 
Bowers, William J. 1964. Student Dishonesty and Its Control in College. New York: Bureau of Applied Social Research, Columbia University.

Burke, Mary A., and Tim R. Sass. 2004. "Classroom Peer Effects and Student Achievement." Presented at the American Economic Association Annual Meetings, Jan 2005.

Case, Anne C., and Lawrence F. Katz. 1991. "The Company You Keep: The Effects of Family and Neighborhood on Disadvantaged Youths." National Bureau of Economic Research Working Paper 3705.

Crutchfield, Richard S. 1955. "Conformity and Character." American Psychologist 10(1):191-98.

Dickey, David A., and Wayne Fuller. 1979. "Distributions of the Estimators for Autoregressive Time Series with a Unit Root." Journal of the American Statistical Association. 74(366):427-31.

Education Trust. 2007. "College Results Online.” Accessed on 16 January 2007 at: http://www.collegeresults.org/

Figlio, David N. 2007. "Boys Named Sue: Disruptive Children and their Peers." Education Finance and Policy 2(4):376-94.

Foster, Andrew D., and Mark R. Rosenzweig. 1995. "Learning by Doing and Learning from Others: Human Capital and Technical Change in Agriculture." Journal of Political Economy 103(6):1176-79.

Foster, Gigi. 2006. "It's Not Your Peers, and It's Not Your Friends: Some Progress Towards Understanding Educational Peer Effects." Journal of Public Economics 90(8-9):1455-75.

Gaviria, Alejandro, and Steven Raphael. 2001. "School-Based Peer Effects and Juvenile Behavior." Review of Economics and Statistics 83(2):257-68.

Gibson, David R., Esther S. Hudes, and David Donovan. 1999. "Estimating and Correcting for Response Bias in Self-Reported HIV Risk Behavior." Journal of Sex Research 35(1):96-101.

Glaeser, Edward L., Bruce L. Sacerdote, and Jose A. Scheinkman. 2003. "The Social Multiplier." Journal of the European Economic Association 1(2-3):345-53.

Graham, Bryan S. 2006. "Identifying Social Interactions through Excess Variance Contrasts." Working paper, University of California, Berkeley.

Hadaway, C. Kirk, Penny Long Marler, and Mark Chaves. 1993. "What the Polls Don't Show: A Closer Look at US Church Attendance." American Sociological Review 58(6):741-52.

Hager, Mark A., Sarah Wilson, Thomas H. Pollak, and Patrick Michael Rooney. 2003. "Response Rates for Mail Surveys of Nonprofit Organizations: A Review and Empirical Test." Nonprofit and Voluntary Sector Quarterly 32(2):252-67.

Hanushek, Eric A., John F. Kain, Jacob M. Markham, and Steven G. Rivkin. 2003. "Does Peer Ability Affect Student Achievement?" Journal of Applied Econometrics 18(5):527-44.

Hoxby, Caroline M., and Gretchen Weingarth. 2005. "Taking Race Out of the Equation: School Reassignment and the Structure of Peer Effects." Working Paper, Harvard University.

Koyner, Kristin. 2006. "10 Things Your College Student Won't Tell You.” Smart Money, August 14, 2006, via Web, http://www.smartmoney.com/10things/index.cfm? story $=$ september 2006

Kremer, Michael, and Dan M. Levy. 2003. "Peer Effects and Alcohol Use Among College Students." NBER Working Paper 9876.

Lefgren, Lars. 2004. "Educational Peer Effects and the Chicago Public Schools." Journal of Urban Economics 56(2):169-91. 
Lyle, David S. 2007. "Estimating and Interpreting Peer and Role Model Effects from Randomly Assigned Social Groups at West Point." Review of Economics and Statistics 89(2):289-99.

Malmstrom, Frederick M., and Richard Coffman. 1991. "Do Honor Codes Work? Following Up 30 Years of Service Academy Graduates." Paper presented to the Rocky Mountain Psychological Association, Denver, Colo.

Manski, Charles F. 1993. "Identification and Endogenous Social Effects: The Reflection Problem." Review of Economic Studies 60(3):531-42.

McCabe, Donald L., Linda Klebe Trevino, and Kenneth D. Butterfield. 2001. "Dishonesty in Academic Environments: The Influence of Peer Reporting Requirements." Journal of Higher Education 72(1):29-45.

McCabe, Donald L., and Linda Klebe Trevino. 1993. "Academic Dishonesty: Honor Codes and Other Contextual Influences." Journal of Higher Education 64(5):522-38.

McCabe, Donald L. 2005. CAI Research. Center for Academic Integrity. http://www. academicintegrity.org/cai_research.asp.

Parry, Hugh J., and Helen M. Crossley. 1950. "Validity of Responses to Survey Questions: Correlated Response Errors in a Panel Study of Voting." Public Opinion Quarterly 14(1):61-80.

Patrick, Donald L., Allen Cheadle, D. C. Thompson, and Paula Diehr. 1994. "The Validity of Self-Reported Smoking: A Review and Meta-Analysis." American Journal of Public Health, 84(7):1086-93.

Princeton Review. 2006. "Colleges and Careers." Accessed on 25 August 2006 at: http:// www.princetonreview.com/college/default.asp

Presser, Stanley, and Linda Stinson. 1998. "Data Collection Mode and Social Desirability Bias in Self-Reported Religious Attendance." American Sociological Review 63(1):137-45.

Presser, Stanley, and Michael Traugott. 1992. "Little White Lies and Social Science Models: Correlated Response Errors in a Panel Study of Voting." Public Opinion Quarterly 14(1):77-86.

Rasmussen, Eric. 1995. "Stigma and Self-Fulfilling Expectations of Criminality." Journal of Law and Economics 39(2):541-43.

Sacerdote, Bruce. 2001. "Peer Effects with Random Assignment: Results for Dartmouth Roommates." Quarterly Journal of Economics 116(2):681-704.

Sah, Raaj K. 1991. "Social Osmosis and Patterns of Crime." Journal of Political Economy 99(6):1272-95.

Silverman, Dan. 2004. "Street Crime and Street Culture." International Economic Review 45(3):761-86.

Spence, Michael. 1973. "Job Market Signaling.” Quarterly Journal of Economics 87(3):355-74.

Stanard, Charles I., and William J. Bowers. 1970. "The College Fraternity as an Opportunity Structure for Meeting Academic Demands." Social Problems 17(3):371-90.

Stinebrickner, Ralph, and Todd R. Stinebrickner. 2006. "What Can Be Learned About Peer Effects Using College Roommates? Evidence From New Survey Data and Students From Disadvantaged Backgrounds." Journal of Public Economics 90(8-9):1435-54.

Sutherland, Edwin Hardin. 1939. Principles of Criminology. Chicago: J. B. Lippincot. Svenson, Ola. 1981. "Are We All Less Risky and More Skillful than our Fellow Drivers?" Acta Psychologica 47(2):143-48.

U.S. News and World Report. 2007. "America's Best Colleges: Lowest Acceptance Rates." Accessed on 16 January 2007 at: http://www.usnews.com/usnews/edu/college/rankings/ brief/webex/lowacc_brief.php 
Vigdor, Jacob, and Thomas Nechyba. 2004. "Peer Effects in North Carolina Public Schools." Unpublished.

Zimmerman, David J. 2003. "Peer Effects in Academic Outcomes: Evidence From a Natural Experiment." The Review of Economics and Statistics 85(1):9-23. 